UDC $342.2 / 331.108 .45$

LBC 67.405.1

\title{
ONGOING EDUCATION OF EMPLOYEES AS AN INNOVATIVE ECONOMY REQUIREMENT
}

\author{
Darya V. Bulavina \\ Ural Institute of Management - Branch of Russian Presidential Academy of National Economy \\ and Public Administration, Ekaterinburg, Russian Federation
}

\begin{abstract}
Introduction: the article addresses the issue of how today labor law governs employees' education, as well as the guarantees and compensation that the employer must provide for employees who combine work and education. These norms are considered through the prism of the emerging innovative economy and actively developing information society. Methods: there are used the general scientific research methods, such as analysis, synthesis, comparison, as well as specific scientific research methods: formal and legal, technical and legal. Results: the author analyzes which role education plays in determining the success of the employee and employer; highlights a number of norms of the Labor Code of the Russian Federation that do not meet the needs of the modern market. Conclusions: the necessity of improvement of the labor legislation in the field of education of the employee is revealed. The specific proposals are made to amend a number of articles of the Labor Code of the Russian Federation.

Key words: education of employee; information society; innovative economy; professional development; professional training of employee; development of labor legislation.
\end{abstract}

УДК $342.2 / 331.108 .45$

ББК 67.405 .1

\section{НЕПРЕРЫВНОЕ ОБРАЗОВАНИЕ РАБОТНИКОВ КАК ТРЕБОВАНИЕ ИННОВАЦИОННОЙ ЭКОНОМИКИ}

\author{
Дарья Владимировна Булавина \\ Уральский институт управления Российской академии народного хозяйства и государственной службы \\ при Президенте РФ, г. Екатеринбург, Российская Федерация
}

Введение: в статье рассматривается как на сегодняшний день в трудовом законодательстве регулируется вопрос образования работников, а также гарантии и компенсации, которые работодатель должен предоставлять работникам, совмещающим трудовую деятельность с получением образования. Данные нормы рассматриваются через призму формирующейся инновационной экономики и активно развивающегося информационного общества. Методы: использованы общенаучные методы исследования, такие как анализ, синтез, сравнение, а также частнонаучные методы исследования (формально-юридический, технико-юридический). Результаты: автор анализирует, какое место на сегодняшний день занимает образование в определении успеха работника и работодателя. Выделяет ряд норм Трудового кодекса РФ, которые не удовлетворяют потребностям современного рынка. Выводы: выявлена необходимость совершенствования трудового законодательства в области образования работника. Сделаны конкретные предложения по внесению изменений в ряд статей Трудового кодекса Российской Федерации.

Ключевые слова: образование работника, информационное общество, инновационная экономика, повышение квалификации, профессиональная переподготовка работника, развитие трудового законодательства.

\section{Введение}

Формирующаяся на сегодняшний день инновационная экономика, характеризуется глобальным информационным потоком, применением научных и технических знаний для создания качественно новых технологий и внедрения их в производство. «В настоящее вре- 
мя уже ни у кого не вызывает сомнения тот факт, что современное общество находится на таком этапе своего развития, когда информация становится одним из ключевых элементов экономики» [5]. Она является одним из главных ресурсов производства, в связи с этим происходит изменение в области трудовых ресурсов, теперь становится приоритетнее высококвалифицированный умственный труд, чем физическая сила.

В условиях рыночной экономики компании соперничают за специалистов, которые обладают большим багажом информации, необходимым для эффективной работы в организации и принесения прибыли. В существующих рыночных условиях только лишь получение хорошего фундаментального образования не является залогом успешной карьеры как в советский период. Немаловажным являются качества работника, которые позволят ему реагировать на изменения в развитии общества, продолжать постоянно развиваться, повышать квалификацию, и даже проходить профессиональную переподготовку в случае необходимости соответствия меняющимся условиям экономики и как следствие спроса на рынке труда. «Инновационное обучение должно работать на будущее» [2, с. 132].

Таким образом, образование в современных экономических условиях является тем самым знанием, ресурсом, который востребован на рынке и так важен для построения эффективного бизнеса, производства, экономики в целом. В связи с этим появляется необходимость больших вложений в обучение, образование, прохождение повышения квалификации и профессиональной переподготовки, а многоуровневость и различные формы образования призваны удовлетворять данные потребности.

\section{Регулирование вопроса образования работника в трудовом законодательстве}

Конвенция Международной организации труда (МОТ) от 23.06.1975 № 142 «О профессиональной ориентации и профессиональной подготовке в области развития людских ресурсов» закрепляет, что каждый работник дол- жен повышать свою квалификацию на протяжении всей трудовой деятельности (ст. 4) [3, с. 1751-1754]. Подобные нормы были сформулированы и в советском законодательстве в Постановлении Госкомтруда СССР, Госкомобразования СССР и Секретариата ВЦСПС от 15 июня 1988 г. № 369/92-14-147/20/18-22 «Об утверждении Типового положения о непрерывном профессиональном и экономическом обучении кадров народного хозяйства» (далее - Типовое положение). Интересно отметить, что данный акт закрепляет прямую обязанность работника постоянно повышать свою квалификацию, что не сделано в Трудовом кодексе Российской Федерации (далее ТК РФ). Работодатель же в свою очередь должен обеспечить ряд условий, например, таких, как создание учебно-материальной базы, изготовление и приобретение технических средств обучения, определять потребность в повышении квалификации сотрудников, разрабатывать и реализовывать планы в данной области и т. д.

Существующие положения ТК РФ декларируют, что прохождение профессиональной подготовки, переподготовки и повышение квалификации является правом работника (ст. 197) и правом работодателя, который, исходя из собственных убеждений и нужд, определяет необходимость подготовки работников по направлениям профессионального образования, профессионального обучения и дополнительного профессионального образования (ст. 196).

Представляется, что действующие нормы ТК РФ не совсем соответствуют потребностям рынка и учитывают интересы, как работника, так и работодателя. Трудовой кодекс РФ предусматривает ряд гарантий и компенсаций не только для работников, которые проходят обучение по направлению работодателя, но и поступающих на обучение самостоятельно. При этом направление и тематика обучения могут быть совершенно не связаны с трудовой деятельностью данного работника. Несмотря на это, работодатель будет вынужден понести определенные затраты, предусмотренные гл. 26 ТК РФ. Видится, что с одной стороны, приняв данные нормы, законодатель частично обеспечил мотивацию граждан к получению образования, с другой 
стороны в достаточно непростых экономических условиях сегодняшнего рынка обрек работодателя на не всегда обоснованные траты. В связи с этим, представляется необходимым задуматься о соответствии данных норм потребностям рынка.

Еще одна из проблем, возникающая при заключении ученического договора, это обязанность работника возместить затраты, понесенные работодателем на его обучение, в случае увольнения сотрудника без уважительной причины, предусмотренная ст. 249 ТК РФ. На практике зачастую возникают спорные ситуации, что считать уважительной причиной, ведь законодательно данный вопрос не урегулирован. В связи с этим подобные споры разрешаются в суде, где формируется различная практика. Так, например, суды первой и апелляционной инстанции диаметрально противоположно оценивают уважительность увольнения в связи с переездом семьи в другую местность.

Некоторые авторы, например, Ю.П. Орловский и В.И. Шкатулла придерживаются позиции, что для определения уважительности причины стоит использовать положения ст. 80 ТК РФ, закрепляющей обстоятельства, позволяющие работнику расторгнуть трудовой договор без предупреждения работодателя за две недели [1]. Ряд судов поддерживает данную позицию, так, например, посчитала необходимым прибегнуть к аналогии, вынося кассационное определение от 30 июня 2010 г. № 33-2593 Судебная коллегия по гражданским делам Вологодского областного суда.

Существует иная позиция, так, например, М.В. Пресняков считает, что причины увольнения, сформулированные в ст. 80 ТК РФ, не применимы в данной ситуации, так как имеют иное «целевое назначение» [4]. В частности, например, в кассационном определении Судебной коллегии по гражданским делам Верховного суда Республики Саха (Якутия) от 21 сентября 2011 года № 33-3509-2011, сформулировано, что выход на пенсию не будет являться уважительной причиной. Помимо этого, не стоит рассматривать в качестве уважительной причины зачисление в образовательное учреждение. Стоит обратить внимание на то, что решение подобных споров каждой ситуации индивидуально. Так, например, низкая оплата труда не будет являться уважительной причиной для расторжения трудового договора, в случае отсутствия иных обстоятельств. Однако, если увольнение по данной причине произошло ввиду необходимости содержания детей, находящихся на иждивении матери после расторжения брака, то суд может принять данное основание как уважительное.

Ввиду вышесказанного, представляется возможным принять Постановление Пленума Верховного суда РФ, которое бы объединило уже существующую на сегодняшний день судебную практику и разъясняло бы, чем стоит руководствоваться судам при разрешении подобных споров.

\section{Выводы}

Учитывая вышесказанное, представляется необходимым совершенствование законодательства в данной области в условиях инновационной экономики и информационного общества. Изменение ст. 2 ТК РФ, путем введения принципа непрерывности образования на протяжении всей трудовой деятельности позволит повысить уровень профессионализма работников, их удовлетворенность трудом, а также уровень развития хозяйствующих субъектов и государства в целом [6, с.120]. Представляется логичным в условиях современного рынка внести изменения в ст. 197 ТК РФ, предусмотрев, что прохождение профессиональной подготовки, переподготовки, повышение квалификации является обязанностью работника. Помимо этого, внести изменения в ст. 173 ТК РФ, определив, что гарантии и компенсации, предусмотренные данной нормой, в случае поступления работника на обучение без направления работодателя, будут предоставляться при наличии связи такого обучения с трудовой деятельностью. В условиях погони стран за информацией и результатами ее применения, совершенствование трудового законодательства в вопросах образования работника позволит участникам экономического процесса через прохождение обучения и подготовку профессиональных кадров максимально использовать возможности современных технологий и ресурсов, что позволит вывести экономику страны на качественно новый уровень. 


\section{СПИСОК ЛИТЕРАТУРЫ}

1. Актуальные проблемы трудового законодательства в условиях модернизации экономики : монография / Е. С. Батусова, И. Я. Белицкая, Э. Н. Бондаренко и др. ; отв. ред. проф. Ю. П. Орловский // М. : Юстицинформ, 2012. - 240 с.

2. Гузенко, В. Н. Экологическое образование в контексте инновационного и модернизационного развития России / В. Н. Гузенко // Вестник Волгоградского государственного университета. Серия 5, Юриспруденция. - 2013. - № 2 (19). - С. 132-136.

3. Конвенции и рекомендации, принятые Международной конференцией труда. 1957-1990. Т. II. - Женева : Международное бюро труда, 1991. C. 1751-1754.

4. Пресняков, М. В. Ответственность работника за увольнение без уважительных причин: проблемы практического применения статьи 249 Трудового кодекса РФ / М. В. Пресняков // Трудовое право. - 2012. - № 2. - С. 71-94.

5. Проскурин, А. С. Понятие правовой информации как основы информационного общества / А. С. Проскурин // Вестник Волгоградского государственного университета. Серия 5, Юриспруденция. - 2016. - № 1 (30). - С. 51-57.

6. Худякова, С. Право на труд и право на образование в современной России. Взаимодействие юридических гарантий / С. Худякова, Е. Брюхина, Н. Новикова. - Saarbrücken : Lap Lambert acad. publ., 2011. $-260 \mathrm{c}$.

\section{REFERENCES}

1. Batusova E.S., Belitskaya I.Ya., Bondarenko E.N. Aktualnye problemy trudovogo zakonodatelstva $v$ usloviyakh modernizatsii ekonomiki: monografiya [Current Problems of Labor Legislation in the Conditions of Economic Modernization: Monograph]. Moscow, Yustitsinform Publ., 2012. 240 p.

2. Guzenko V.N. Ekologicheskoe obrazovanie v kontekste innovatsionnogo i modernizatsionnogo razvitiya Rossii [Ecological Education in the Context of Russia's Innovative and Modernization Development]. Vestnik Volgogradskogo gosudarstvennogo universiteta. Seriya 5, Yurisprudentsiya [Science Journal of Volgograd State University. Jurisprudence], 2013, no. 2 (19), pp. 132-136.

3. Konventsii i rekomendatsii, prinyatye Mezhdunarodnoy konferentsiey truda. 1957-1990. T. II. [Conventions and Recommendations Adopted by the International Labor Conference. 1957-1990. Vol. II]. Zheneva, Mezhdunarodnoe byuro truda, 1991, pp. 1751-1754.

4. Presnyakov M.V. Otvetstvennost rabotnika za uvolnenie bez uvazhitelnykh prichin: problemy prakticheskogo primeneniya statyi 249 Trudovogo kodeksa RF [Responsibility of the Employee for Dismissal Without Good Reason: the Problems of Practical Application of Article 249 of the Labor Code of the Russian Federation]. Trudovoe pravo, 2012, no. 2, pp. 71-94.

5. Proskurin A.S. Ponyatie pravovoy informatsii kak osnovy informatsionnogo obshchestva [The Concept of Legal Information as the Basis of the Information Society]. Vestnik Volgogradskogo gosudarstvennogo universiteta. Seriya 5, Yurisprudentsiya [Science Journal of Volgograd State University. Jurisprudence], 2016, no. 1 (30), pp. 51-57.

6. Khudyakova S., Bryukhina E., Novikova N. Pravo na trud i pravo na obrazovanie v sovremennoy Rossii. Vzaimodeystvie yuridicheskikh garantiy [The Right to Work and the Right to Education in Modern Russia. Interaction of Legal Guarantees]. Saarbrücken, Lap Lambert acad., 2011. 260 p.

\section{Information about the Author}

Darya V. Bulavina, Postgraduate Student, Department of Social Law, Ural Institute of Management Branch of Russian Presidential Academy of National Economy and Public Administration, 8 Marta St., 66, 620144 Ekaterinburg, Russian Federation, dvn130193@yandex.ru.

\section{Информация об авторе}

Дарья Владимировна Булавина, аспирант кафедры социального права, Уральский института управления Российской академии народного хозяйства и государственной службы при Президенте РФ, ул. 8 Марта, 66, 620144 г. Екатеринбург, Российская Федерация, dvn130193@yandex.ru. 